Plant Tissue Cult. \& Biotech. 22(2): 143-152, 2012 (December)

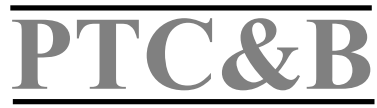

\title{
In vitro Propagation in Three Varieties of Gerbera (Gerbera jamesonii Bolus.) from Flower Bud and Flower Stalk Explants
}

\author{
Nazma Akter*, M.I. Hoque and R.H. Sarker \\ Plant Breeding and Biotechnology Laboratory, Department of Botany, University of \\ Dhaka, Dhaka-1000, Bangladesh \\ Key words: Propagation, Gerbera jasmesonii, Flower bud, Flower stalk
}

\begin{abstract}
Three types of tender leaves derived explants such as leaf tip, leaf with mid-rib and leaf blade segments as well as flower buds and flower stalks obtained from three selected varieties of gerbera (Gerbera jamesonii Bolus.) cultivated in Bangladesh were exploited for callus induction and in vitro regeneration of plantlets. Among the explants flower bud and flower stalk were suitable and superior for callus induction and subsequent regeneration of in vitro shoots when cultured on MS supplemented with $5.0 \mathrm{mg} / \mathrm{l} \mathrm{BAP}$ and $1.0 \mathrm{mg} / \mathrm{l}$ NAA. However, highest number of multiple shoots were obtained when the flower bud derived callus was subcultured on MS supplemented with $2.0 \mathrm{mg} / \mathrm{l} \mathrm{BAP}$. Variety with red petal showed the best response in producing multiple shoots among the three varieties. Root induction at the base of the in vitro regenerated shoots was tried using full and half the strengths of MS containing different concentrations of IBA. Best root induction was observed on half the strength of MS supplemented with $0.2 \mathrm{mg} / \mathrm{l}$ IBA. Following adequate acclimatization the regenerated plantlets were successfully transferred to soil where they grew to maturity and produced flowers.
\end{abstract}

\section{Introduction}

Gerbera, commonly known as African daisy, produces very attractive flowers. It is a genus of ornamental plants belongs to Asteraceae. Gerbera produces flowers of commercial interest throughout the world covering a wide range of climatic conditions and it is widely used as a decorative garden plant or as cut flowers. Gerbera ranks among the top ten cut flowers of the world (Parthasarathy and Nagaraju 1999).

*Author for correspondence: <naz_ma08@yahoo.com) 
The growth of floriculture industry has taken long strides world-wide especially in the developing countries as a result of outsourcing which is due to low cost of maintenance including low labor cost (Jain 2006). For that reason gerbera has gained popularity in the past few years in many countries of the world and it is in great demand in the floral industry as cut flower as well as potted plant due to its beauty, color, long vase life (Kanwar and Kumar 2008). The market value of gerbera is high in the US, Japan, Germany and in the UK. In Europe, the Netherlands and in Asia Indonesia as well as Malaysia are the dominant gerbera suppliers world-wide. In Bangladesh, public attraction is gradually increasing particularly in urban areas about gerbera as ornamental and home decorative plants for its attractive colors and size. However, the supply of gerbera plantlets is not adequate to fulfill the local demand. It may be mentioned here that Bangladesh has a favorable climatic condition and is capable of producing a wide array of gerberas of international standard (http://www. mdgbangla.org).

In light of global demand, gerbera could be a major source of foreign exchange as one of the non-traditional export items in Bangladesh. In this aspect, mass commercial production of gerbera could be acted as a new dimension in Bangladesh economy. However, using conventional propagation system it is simply not possible to fulfill the demand of the export market. Seed propagation in gerbera is not always satisfactory since impurity of strain produces a great deal of variations (Schiva 1975). Moreover, traditional seed production technique is too slow for their exploitation in commercial purposes (Murashige et al. 1974). It also requires longer time to produce flower.

Vegetative propagation overcomes the problem of unpredictable characters and plants obtained by this method perform better than those developed from seeds. In vitro techniques of propagation have been recognized as the preferred method for multiplication of selected elite clones (Reynoird et al. 1993, Aswath and Choudhary 2002, Xi and Shi 2003, Prasanth and Sekar 2004, Kumar et al. 2004, Chakrabarty and Datta 2007 and http://www.bari.gov.bd).

A survey of literature indicates that tissue culture of Gerbera has been studied by various scientists using different types of explants (Barbosa et al. 1994, Parthasarathy et al. 1997, Le et al. 1999, Posada et al. 1999, Zhang et al. 2002, Modh et al. 2002, Tyagi and Kothari 2004, Aswath and Wanzeen 2004, Thakur et al. 2004, Kumar and Kanwar 2005, 2006, Sharma and Srivastava 2005 and Ray et al. 2005). However, the in vitro propagation systems described by various scientists in the past need to be improved further in view of their reproducibility in respect to the conditions prevail in Bangladesh. The present investigation was undertaken with a view to developing an in vitro plant regeneration protocol for 
large scale propagation of selected Gerbera varieties cultivated in Bangladesh using suitable explants.

\section{Materials and Methods}

Plants of three varieties of gerbera (Gerbera jamesonii Bolus.) having red, yellow and white coloured petals collected from BRAC Research and Development Centre, Joydebpur, Gajipur and were used for this study. Tender leaves and 2.5 $4.0 \mathrm{~cm}$ long flower buds (9 - 11 days old) along with flower stalks were collected from the field grown materials. Special treatments were applied to reduce the level of contamination since field grown materials were used for this investigation. Leaves and flower buds with stalks were first washed under running tap water for $30 \mathrm{~min}$. Then the explants were washed with detergent and then the detergent was washed out completely. The explants were then immersed in $20 \%$ Savlon (v/v), an antiseptic disinfectant containing chlorhexidine gluconate and cetrimide (Novartis Consumer Health UK Ltd.) for 2 min followed by washing with distilled water. After that the explants were treated with a fungicide called bendagime $(1.0 \mathrm{gm} / 500 \mathrm{ml})$ for $5 \mathrm{~min}$ followed by several washing with distilled water. The explants were then deepened in $70 \%$ alcohol for 30 seconds followed by washing three times with distilled water. The final surface sterilization of the explants was done with $0.1 \% \mathrm{HgCl}_{2}$ solution for 6 - 7 min inside the laminar flow cabinet. During this operation, the flask was agitated frequently and finally the explants were washed five times with sterilized distilled water.

For inoculation the surface sterilized leaf explants were cut into three pieces, namely leaf tip, leaf with mid-rib and leaf blades. One - two cm long segments of these leaves derived explants were cultured for callus induction and shoot multiplication. On the other hand the surface sterilized flower buds were dissected into 8 - 10 pieces for using them as explants (Fig. 1). About $1-2 \mathrm{~cm}$ long segments of petiole and flower stalks were also used as explants for callus induction and in vitro regeneration.

MS supplemented with different concentrations and combinations of BAP $(1.0-6.0 \mathrm{mg} / \mathrm{l})$, NAA $(0.5-2.0 \mathrm{mg} / \mathrm{l})$ were used for the induction of callus and development of multiple shoots from different explants of three varieties. All media contained 3\% sucrose and $0.8 \%$ agar with $\mathrm{pH} 5.8$, adjusted before autoclaving. For rooting $3-4 \mathrm{~cm}$ long regenerated shoots were excised and cultured on freshly prepared rooting medium containing full and half strength of MS with different combinations and concentrations of IBA and NAA. All cultures were maintained less than $16 \mathrm{hrs}$ photoperiod at $25 \pm 2^{\circ} \mathrm{C}$. Following the

development of sufficient roots, plantlets were transferred to small plastic pots 
containing sterilized soil. These plantlets were acclimated and then transferred to the field and raised there till their maturity to flowering.

\section{Results and Discussion}

Various explants, namely flower bud, flower stalk, leaf tip, leaf with midrib, leaf blade, petiole were used for callus induction and in vitro development of plantlets. Among the different explants, flower bud exhibited the best response towards callus formation, shoot regeneration and subsequent development of plantlets in three varieties of gerbera. The age of the flower bud was found to be an important factor in callus induction and shoot proliferation. In all the varieties 7 - 9 days old flower buds were more responsive (80 - 90\%) in callus induction and shoot proliferation (Table 1). There are some previous reports on using of flower bud as explants for shoot regeneration in gerbera (Pierik et al. 1975, Laliberte et al. 1985, Aswath and Choudhary 2002, Tyagi and Kothari 2004, Ray et al. 2005, Kumar and Kanwar 2006, 2007 and Nhut et al. 2007).

Table 1. Responses of the age of flower bud explants towards callus formation.

\begin{tabular}{lcccc}
\hline $\begin{array}{l}\text { Gerbera } \\
\text { varieties }\end{array}$ & $\begin{array}{c}\text { Age of flower } \\
\text { bud explants } \\
\text { (days) }\end{array}$ & $\begin{array}{c}\text { No. of } \\
\text { explants } \\
\text { inoculated }\end{array}$ & $\begin{array}{c}\text { No. of explants } \\
\text { responded to } \\
\text { callus induction }\end{array}$ & $\begin{array}{c}\% \text { of } \\
\text { responsive } \\
\text { explants }\end{array}$ \\
\hline Red variety & 7 & 20 & 09 & 45 \\
& 8 & 20 & 13 & 65 \\
& 9 & 20 & 17 & 85 \\
Yellow variety & 10 & 20 & 14 & 70 \\
& 7 & 20 & 10 & 50 \\
\hline White variety & 8 & 20 & 16 & 80 \\
& 9 & 20 & 14 & 70 \\
& 10 & 20 & 11 & 55 \\
& 11 & 20 & 09 & 45 \\
& 7 & 20 & 06 & 90 \\
& 9 & 20 & 18 & 65 \\
& 10 & 20 & 13 & 65 \\
& 11 & 20 & 13 & 55 \\
\hline
\end{tabular}

In the present study, flower stalk was also appeared to be a good responsive explant towards callus formation and shoot regeneration. None of the previous workers used flower stalk explant for shoot regeneration.

In case of red variety, all the leaf derived explants induced callus within 18 20 days on MS with $6.0 \mathrm{mg} / \mathrm{l} \mathrm{BAP}$ and $1.0 \mathrm{mg} / \mathrm{l} \mathrm{NAA}$ depending on the nature of 
the explant. In case of yellow and white varieties all the explants induced callus within 15 - 20 days on MS supplemented with either 5.0 or $6.0 \mathrm{mg} / \mathrm{l} \mathrm{BAP}$ with 1.0 $\mathrm{mg} / \mathrm{l} \mathrm{NAA}$, respectively. The induced calli were subcultured initially on the same medium having the identical hormonal supplements for shoot regeneration.

Following such subculture the induced calli were found to increase their volume, but failed to induce shoots irrespective of variety as well as explants used. However, a few reports are available about in vitro shoot regeneration from different parts of leaf including petiole (Orlikowska et al. 1999).

Table 2. Effect of different concentrations of BAP and NAA on shoot regeneration via callus formation from flower bud and flower stalk explants for red variety.

\begin{tabular}{|c|c|c|c|c|c|c|c|}
\hline \multicolumn{2}{|c|}{$\begin{array}{c}\text { Hormonal } \\
\text { supplements } \\
(\mathrm{mg} / \mathrm{l}) \\
\end{array}$} & \multirow[t]{2}{*}{$\begin{array}{c}\text { No. of } \\
\text { explants } \\
\text { inoculated }\end{array}$} & \multirow[t]{2}{*}{$\begin{array}{c}\text { Days to } \\
\text { callus } \\
\text { induction }\end{array}$} & \multirow[t]{2}{*}{$\begin{array}{c}\text { No. of } \\
\text { responsive } \\
\text { explants }\end{array}$} & \multirow[t]{2}{*}{$\begin{array}{c}\text { \% of } \\
\text { responsive } \\
\text { explants }\end{array}$} & \multirow[t]{2}{*}{$\begin{array}{l}\text { Days to } \\
\text { shoot } \\
\text { initiation }\end{array}$} & \multirow[t]{2}{*}{$\begin{array}{c}\text { Mean no. of } \\
\text { shoots per } \\
\text { explant }\end{array}$} \\
\hline BAP & NAA & & & & & & \\
\hline \multicolumn{8}{|c|}{ Flower bud } \\
\hline 1.0 & 0.5 & 30 & 35 & Only callus & - & - & - \\
\hline 2.0 & 0.5 & 30 & $35-45$ & $"$ & - & - & - \\
\hline 3.0 & 1.0 & 30 & $35-45$ & 06 & 20 & $30-35$ & 3.16 \\
\hline 4.0 & 1.0 & 30 & $35-45$ & 12 & 40 & $25-30$ & 5.17 \\
\hline 5.0 & 1.0 & 30 & $35-45$ & 22 & 73 & $22-25$ & 9.5 \\
\hline 6.0 & 1.0 & 30 & $35-45$ & 10 & 33 & $28-30$ & 2.3 \\
\hline \multicolumn{8}{|c|}{ Flower stalk } \\
\hline 1.0 & 0.5 & 30 & $45-60$ & Only callus & - & - & - \\
\hline 2.0 & 0.5 & 30 & $45-60$ & $"$ & - & - & - \\
\hline 3.0 & 1.0 & 30 & $45-60$ & $"$ & - & - & - \\
\hline 4.0 & 1.0 & 30 & $45-60$ & 06 & 20 & $25-30$ & 4.1 \\
\hline 5.0 & 1.0 & 30 & $45-60$ & 16 & 54 & $20-25$ & 7.37 \\
\hline 6.0 & 1.0 & 30 & $45-60$ & 11 & 37 & $25-30$ & 3.23 \\
\hline
\end{tabular}

In all the three varieties of gerbera the best response regarding the induction of callus and proliferation of multiple shoots was obtained when flower bud explants were cultured on MS supplemented with $5.0 \mathrm{mg} / \mathrm{l} \mathrm{BAP}$ and $1.0 \mathrm{mg} / \mathrm{l}$ NAA. Initiation of callus occurred within three weeks after inoculation. The percentage of responsive explants in respect of shoot regeneration was around 75 - 83 and mean number of shoots per explant varied from 9 - 12 in all the varieties. Initiation of shoots from proliferated callus is presented in Fig. 2.

In case of flower stalk explant, higher number of multiple shoots in all the three varieties of gerbera was also observed on MS supplemented with $5.0 \mathrm{mg} / \mathrm{l}$ $\mathrm{BAP}$ and $1.0 \mathrm{mg} / \mathrm{l} \mathrm{NAA}$. The percentage of responsive explants regarding shoot 
regeneration was around $54-68$ and mean number of shoots per explant was 8 - 10 in all the varieties. Multiple shoots initiated in MS with $5.0 \mathrm{mg} / \mathrm{l} \mathrm{BAP}$ and $1.0 \mathrm{mg} / \mathrm{l}$ NAA from the flower stalk explants (Fig. 3) were green and healthy.

Table 3. Effect of subculturing on MS with different concentrations of BAP for multiple shoot regeneration in red variety.

\begin{tabular}{lccccc}
\hline $\begin{array}{l}\text { Hormonal } \\
\begin{array}{l}\text { supplement } \\
\text { BAP }(\mathrm{mg} / \mathrm{l})\end{array}\end{array}$ & Explants & $\begin{array}{c}\text { No. of } \\
\text { subculturing } \\
\text { clumps }\end{array}$ & $\begin{array}{c}\text { \% of } \\
\text { responsive } \\
\text { clumps }\end{array}$ & $\begin{array}{c}\text { Mean no. of shoots/ Mean length } \\
\text { subculturing } \\
\text { clumps }\end{array}$ & $\begin{array}{c}\text { of shoot }(\mathrm{cm}) \\
\text { after 120 days }\end{array}$ \\
\hline 01 & FB & 30 & 80.50 & 20.50 & 2.5 \\
\hline 02 & FS & 30 & 78.23 & 15.25 & 2.8 \\
\hline 03 & FB & 30 & 98.25 & 28.64 & 4.6 \\
& FS & 30 & 94.86 & 18.15 & 4.1 \\
\hline 04 & FB & 30 & 75.78 & 14.80 & 3.7 \\
& FS & 30 & 72.57 & 08.75 & 2.9 \\
\hline
\end{tabular}

$\mathrm{FB}=$ Flower bud, FS = Flower stalk.

Response of callus induction and shoot proliferation was significantly influenced by the concentrations and combinations of cytokinins and auxins. Profuse shoot proliferation occurred in all the three varieties of gerbera when MS was supplemented with BAP and NAA. Hasbullah et al. (2008) also reported that addition of auxins along with cytokinins was essential for shoot induction in gerbera. When BAP was supplemented with IAA callus was induced but no shoot proliferated. On the other hand when BAP was supplemented with NAA, in some combinations callus induction as well as shoot proliferation occurred. Pierik et al. (1973) also reported that addition of strong auxin (NAA) with BAP promoted better shoot formation compared to weak auxin (IAA).

It was noticed that when the regenerated shoots were cultured and maintained on MS supplemented with $5.0 \mathrm{mg} / \mathrm{l} \mathrm{BAP}$ and $1.0 \mathrm{mg} / \mathrm{l} \mathrm{NAA}$ for longer duration for further shoot multiplication, the previously regenerated shoots became stunted in growth and vitrified. To overcome this problem shoots were cultured on MS containing only BAP. Chakrabarty and Datta (2008) obtained best shoot multiplication on MS containing only BAP, Kn and TDZ.

During this study different concentrations of BAP $(1.0-4.0 \mathrm{mg} / \mathrm{l})$ were tested for shoot multiplication. Best response (Table 3) towards multiple shoot regeneration from callus obtained from flower bud was observed on MS with 2.0 $\mathrm{mg} / \mathrm{l} \mathrm{BAP}$ in all the three varieties of gerbera (Figs 4 and 5). In this hormonal supplement the mean number of shoots in flower bud and flower stalk explants were 28.64 and 18.15 , respectively. 

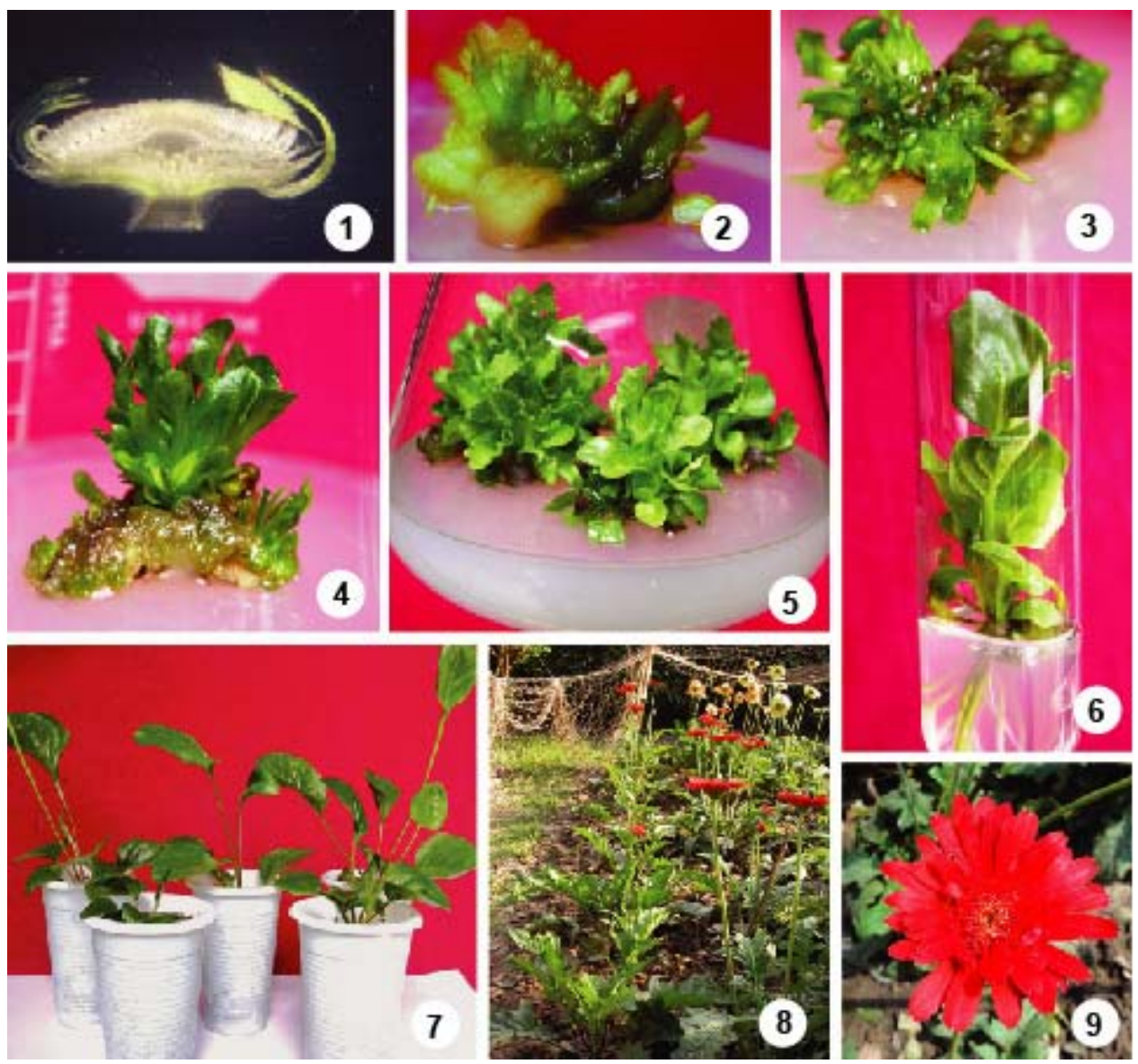

Figs 1-9: 1. Transverse section of flower bud used as explant for callus induction and shoot regeneration. 2. Induction of shoots from the flower bud derived callus. 3. Regeneration of multiple shoots from the flower stalk explant. 4. Induction of shoot from flower bud derived callus following subculturing. 5. Same as Fig. 4 but showing the proliferation of shoots. 6 . Elongated in vitro roots developed at the base of the regenerated shoot. 7 . Regenerated plantlets transferred to plastic pots. 8. In vitro propagated plants. 9. Flower developed from tissue cultured derived plant.

Induction of healthy root system from the regenerated shoots is an essential part for successful development of plantlets. During the present study it was noticed that several roots developed spontaneously from the in vitro grown shoots but the spontaneously developed roots were found to be inadequate for transplantation of the in vitro grown shoots to the soil. Therefore, separate root induction was necessary.

For root induction, regenerated shoots were cultured on half and full strength of MS supplemented with IBA, IAA and NAA. It was observed that half strength of MS with $0.2 \mathrm{mg} / \mathrm{l}$ IBA showed $95-100 \%$ for root induction in the red, 
yellow and white varieties (Fig. 6). Kanwar and Kumar (2006) also reported that IBA was the best medium for root induction in Gerbera. When NAA was used at 0.1 and $0.2 \mathrm{mg} / \mathrm{l}$ with half the strength of MS, only callus was induced. Efforts were made to establish plantlets in pots with proper root systems (Fig. 7). Plants with sufficient roots were transplanted to soil (Fig. 8) and their survival rate was $100 \%$ in the field condition. These tissue culture derived plants flowered (Fig. 9) very much identical to that of the control plants.

Table 4. Effect of different auxins on root formation in red variety.

\begin{tabular}{lcccc}
\hline $\begin{array}{l}\text { Growth } \\
\text { regulators }(\mathrm{mg} / \mathrm{l})\end{array}$ & $\begin{array}{c}\text { \% of shoots } \\
\text { forming roots }\end{array}$ & $\begin{array}{c}\text { Days to root } \\
\text { initiation }\end{array}$ & $\begin{array}{c}\text { Days to root } \\
\text { development }\end{array}$ & $\begin{array}{c}\text { Nature of } \\
\text { the roots }\end{array}$ \\
\hline IAA 0.1 & 27 & $20-25$ & $40-45$ & Long \& thin \\
IAA 0.2 & 38 & $20-25$ & $40-45$ & $"$ \\
IBA 0.1 & 62 & $15-20$ & $35-40$ & $"$ \\
IBA 0.2 & 100 & $15-20$ & $35-40$ & $"$ \\
NAA 0.1 & Only callus & - & - & - \\
NAA 0.2 & $"$ & - & - & - \\
\hline
\end{tabular}

All the three Gerbera varieties used in this study showed almost identical responses towards in vitro regeneration. The overall responses of the red petal variety were found to be relatively better compared to the other two varieties of local gerbera.

Through this investigation it has been possible to develop an efficient and reproducible in vitro mass propagation system from different explants of gerbera. Based on the results it may be concluded that the in vitro mass propagation protocol developed in this investigation could profitably be explored for the commercial cultivation of gerbera. The present protocall of propagation may help in obtaining adequate number of plantlets for cultivation in fulfilling the requirements of the local market of gerbera.

\section{References}

Aswath CR and Choudhary MI (2002) Rapid plant regeneration from Gerbera jamesonii. Acta Bot. Croat. 61(2): 125-134.

Aswath C and Wazneen S (2004) An improved method for in vitro propagation of gerbera. Journal of Ornamental Horticulture 7: 141-146.

Barbosa MHP, Pinto JEBP, Pinto CABP and Innecco R (1994) In vitro propagation of Gerbera jamesonii Bolus ew Hook cv. 'Appelbloesem' using young capitulums. Revista Ceres 41: 386-395.

Chakrabarty D and Datta SK (2007) Micropropagation of gerbera: lipid peroxidation and antioxidant enzyme activities during acclimatization process. Acta Physiologiae Plantarum (online publication 2007). 
Chakrabarty D and Datta SK (2008) Micropropagation of gerbera: lipid peroxidation and antioxidant enzyme activities during acclimatization process. Acta Physiol Plant. 30: 325-331.

Hasbullah NA, Taha RM and Awal A (2008) Growth Optimization and Organogenesis of Gerbera jamesonii Bolus ex Hook f. in vitro. Pakistan Journal of Biological Sciences. 11(11): 1449-1454.

Jain SM 2006. Mutation assisted breeding for improving ornamental plants. ISHS Acta Horticulturae 714(1).

Kanwar JK and Kumar S (2008) In vitro propagation of Gerbera- A Review, Hort. Sci. (Prague) 35(1): 35-44.

Kumar S, Kanwar JK and Sharma DR (2004) In vitro regeneration of Gerbera jamesonii Bolus from leaf and petiole explants. J. Plant Biochem. Biotechnol. 13: 73-75.

Kumar, S. and Kanwar JK (2005) Plant regeneration from callus and cell suspension cultures of Gerbera jamesonii Diablo. European Journal of Horticultural Science 70: 265-270.

Kumar S and Kanwar JK (2006) Regeneration ability of petiole, leaf and petal explants in gerbera cut flower cultures in vitro. Folia Horticulturae 18: 57-64.

Kumar S and Kanwar JK (2007) Plant regeneration from cell suspensions in Gerbera jamesonii Bolus. J. Fruit and Ornamental Plant Research 15: 157-166.

Laliberte S, Chretien I and Vieth J (1985) In vitro plantlet production from young Capitulum explants of Gerbera jamesonii. Hort. Sci. 20: 137-139.

Le CL, Julmi C, Thomas D and Tschuy F (1999) In vitro regeneration and multiplication of Gerbera jamesonii Bolus. Revue Suisse de Viticulture, d' Arboriculture et d' Hort. 31: 207-211.

Modh FK, Dhaduk BK and Shah RR (2002) Factors affecting micropropagation of gerbera from Capitulum explants. J. Ornamental Horticulture 5: 4-6.

Murashige T, Serpa M and Jones JB (1974) Clonal multiplication of gerbera through tissue culture. Hort. Science 9: 175-180.

Nhut DT, Huong NTD, Don NT, Hai NT, NThien NQ and Vu NH (2007) Effect of genotype, explant size, position and culture medium on shoot generation of Gerbera jamesonii by receptacle transverse thin cell layer culture. Scientia Horticulturae 111(24): 146-151.

OrlikowskaT, Nowak E, Marasek A and Kucharska D (1999) Effects of growth regulators and incubation period on in vitro regeneration of adventitious shoots from gerbera petioles. Plant Cell, Tissue Org. Cult. 59: 95-102.

Parthasarathy VA, Parthasarathy U, Nagarju V and Mishra M (1997) Callus induction and subsequent plant regeneration from leaf explants of Gerbera jamesonii. Folia Hort. 9(2): 83-86.

Parthasarathy VA and Nagaraju V (1999) In vitro propagation in Gerbera jamesonii Bolus. Indian Journal of Horticulture 56: 82-85.

Pierik RLM, Steegmans NHM and Marelis JJ (1973) Gerbera plantlets from in vitro cultivated Capitulum explants. Scientia Horticulturae 1: 117-119.

Pierik RLM, Jansen JLN, Maasdan A and Binnendijk CM (1975) Optimization of gerbera plantlet production from excised capitulum explants. Sci. Hort. 3: 351-357. 
Posada M, Ballesteros N, Obando W and A. Angarita A (1999) Micropropagation of gerbera from floral buds. Acta Hort. 482: 329-332.

Prasanth M and Sekar K (2004) Studies on age of explant on callus induction in gerbera cv. Mammut. Scientia Horticulturae 9: 207-211.

Ray T, Saha $\mathbf{P}$ and Roy $\mathbf{R}$ (2005) In vitro plant regeneration from young capitulum explants of Gerbera jamesonii. Plant Cell Biotechnology and Molecular Biology 6: 35-40.

Reynoird PC, Chriqui D, Noin M, Brown S and Marie D (1993) Plant propagation from in vitro leaf culture of several Gerbera species. Plant cell, Tissue Org. Cult. 33. 203-210.

Schiva T (1975) Miglioramento genetico della Gerbera. Analisi genetica dei caratteri metrici di importanza commerciale e conseguenze dell'inincrociol. I. Genet. Agr. 29: 233-240.

Sharma G and Srivastava R (2005) Combinations and concentrations of growth regulators for somatic embryogenesis in gerbera. Ann. Agril. Res. 26: 214-217.

Thakur PS, Ghorade RB and Rathod HT (2004) Micropropagation studies in gerbera. Annals of Plant Physiology 18: 133-173.

Tyagi P and Kothari SS (2004) Rapid in vitro regeneration of Gerbera jamesonii (H. Bolus ex Hook f.) from different explants. Indian J. Biotech. 3: 584-586.

Xi M and Shi JS (2003) Tissue culture and rapid propagation of Gerbera jamesonii. Journal Wanjing Forestry University 27: 33-36.

Zhang W (2002) Research on rapid propagation of Gerbera jamesonii. Fujian Agric. Sci. Technol. 1: 17-18.

Website Consultation

- http://www.bari.gov.bd/non_commodity_achievement/biotechnology-2.htm - 41k

- http://www.mdgbangla.org/striving_mdg/goal1/actors/individual/flower/indiv_flow er.htm. 